well as on chance, technology and other subjects, Cage became both a public intellectual and a celebrity.

The BBC Radiophonic Workshop also regularly replenished its perspective by rotating its personnel. At first, this was a deliberate strategy by BBC managers. Electronic audio was so unfamiliar when the studio formed in 1958 that managers felt engineers could only work on sound effects "for a limited amount of time before succumbing to mental instability". Niebur reveals the bureaucracy and political manoeuvrings inherent in the government-funded behemoth that is the BBC. Later, many studio hands left for better-paid jobs at private companies - among them such seminal individuals in the history of electronic music as Delia Derbyshire and Daphne Oram, the latter of whom went on to influence film and opera and develop new instruments.

There are parallels between the two books. The Radiophonic faithfully served the $\mathrm{BBC}$, and Cage composed reams of music for his lover Merce Cunningham's dance company. Both institutions pioneered tape loops and other techniques, and each associated closely with natu-

"Managers felt
engineers could
only work on
sound effects 'for
a limited amount
of time before
succumbing
to mental
instability'."
ralists - Cage idolized philosopher Henry David Thoreau, and the Radiophonic team wrote ardently for wildlife broadcaster David Attenborough. Both performed for a global audience, yet their paths rarely crossed.

Differences emerge in their philosophies. Cage was intellectually highbrow, but the Radiophonic members were chartered populists. Cage loomed large in European universities and cultural institutions in Germany, France and Italy. The Radiophonic, although equally inventive, defined itself by remaining opposed to such academic forces. It avoided ideological battles about the political nature of the orchestra or about musical structures such as 12-tone serialism, in which Cage participated. The Radiophonic was, Niebur says, "the first studio in the world to make electronic music accessible to ordinary people". Its legacy lives on in the latest return to our screens of Doctor Who - featuring yet another rendition of that indelible theme tune.

Marc Weidenbaum is a writer based in San Francisco, California, and blogs at http://disquiet.com.

e-mail:marc@disquiet.com

\title{
ETHICS
}

\section{The good life}

\section{Pascal Boyer assesses what science has to say about morals.}

$\mathrm{P}$ hilosopher David Hume wrote in the eighteenth century that one cannot derive an 'ought' from an 'is'. In The Moral Landscape, journalist Sam Harris counters this view, arguing that science can shed light on why we hold moral values and also say which values are valid. In doing so, he eloquently counters the jaded pessimists who think that science has little to say about happiness. His thesis is compelling, but he underplays the extent to which our decisions are rooted in intuition, preferring to portray decision-making as a calculated maximization of our well-being.

The psychology of morality is a rapidly growing field. Investigations of brain processes involved in moral intuitions, feelings and judgements reveal a suite of sophisticated mental capacities, fine-tuned by natural selection, that orchestrate our reactions to other people's behaviours and to our own. In distributing resources, for example, people are sensitive to differences in need and merit as well as welfare. In most circumstances, people experience moral judgements as gut feelings, produced by largely unconscious processes. Our moral reasoning is thus an awkward attempt to rationalize these intuitive feelings.

This nuanced scientific perspective is far from the hackneyed picture of virtue being a culturally derived imprint, imposed for the benefit of society on an instinctive beast. It shows how moral sentiment may have played a part in our evolution, conferring fitness advantages on ethically inclined individuals. But Harris goes further, arguing that humans can intuitively distinguish 'the good life' which maximizes individual well-being from less-optimal alternatives. Moral courses of action, he suggests, are those that lead us closer to this positive ideal. Scientific research addresses morality by explaining how our actions contribute to our well-being.

Harris runs against the intellectual grain in stating that moral choices can be set on an objective scale - those that increase wellbeing versus those that do not - and that societies are capable of moral progress, such as outlawing slavery or torture. Both views oppose the prevailing position of moral relativism, which supposes that the suffering is justifiable if it fits some local custom. Harris punctures such incoherent philosophy easily.

If morals are fluid, what should be our yardstick of valid choices? Religion is ruled out. Harris's brand of consequentialism - the ends justify the means, so what is good is what maximizes well-being - excludes transcendent

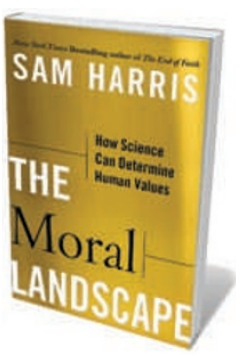

sources. Because there is a quantifiable outcome, we do not need a deity to know whether our choice had good or bad consequences. Harris points out that most of the choices that are spread in the name of religion, such

The Moral Landscape: How Science Can Determine Human Values SAM HARRIS

The Free Press: 2010. 304 pp. $\$ 26.99$

But science and intuition are not always reliable. The case against mugging people is easy to make, by quantifying suffering and benefit and the net result on the level of wellbeing. But an issue such as abortion is more difficult: our feelings are grounded in our intuition about whether a fetus is a person. Our idea of personhood has evolved as an approximation that is sufficient in our social interactions. Such ideas typically founder on limiting cases - we simply cannot know whether a brain-dead individual or an unborn fetus is a person or not. Harris sees such conundrums as difficult, unsolved scientific puzzles that we should pursue.

A moral optimist, Harris suggests that people can be persuaded to abandon harmful behaviours, such as the stoning of adulterers. Here, social scientists may feel that he rides roughshod over some solid findings of moral psychology. Consequentialism is not the heuristic of most humans. Experiments show that assessments of well-being are of less importance in moral decision-making than a gut feeling that actions are wrong or right. For example, beyond its genetic risks, people maintain that sibling incest is wrong, even in cases where no children result.

To be persuaded that some actions are immoral because they diminish well-being, people need to accept that welfare is the most relevant criterion of morality, which may require a special education. This and many other difficulties stand in the way of Harris's moral reforms, but they are all reasons to read his lucid, deep and uncompromising essay.

Pascal Boyer is Henry Luce Professor of Individual and Collective Memory at Washington University, St Louis, USA. 